\title{
INCORPORATION OF RADIOACTIVE TRACERS OF SOME LABELLED COMPOUNDS INTO DNA, RNA, AND PROTEIN IN CHLORELLA CELLS AT VARIOUS STAGES OF THE CELL CYCLE IN SYNCHRONOUS CULTURE
}

\author{
AKIKO TAKABAYASHI, TAKAO NISHIMURA, AND TATSUICHI IWAMURA \\ Research Institute for Biochemical Regulation, Faculty of Agriculture, \\ Nagoya University, Chikusa-ku, Nagoya 464
}

(Received April 1, 1976)

\begin{abstract}
Radioisotopically labelled compounds $\left({ }^{14} \mathrm{CO}_{2},{ }^{32} \mathrm{P}\right.$-phosphates, $\left[2-{ }^{14} \mathrm{C}\right]-$ acetate, L- $\left[4,5-{ }^{3} \mathrm{H}\right]$ leucine, $\left[6-{ }^{3} \mathrm{H}\right]$ thymidine, $\left[2-{ }^{14} \mathrm{C}\right]$ thymine, $\left[5-{ }^{3} \mathrm{H}\right]-$ uridine and $\left[2-{ }^{14} \mathrm{C}\right]$ uracil) were fed for $1 \mathrm{hr}$ to synchronized Chlorella cells at various stages of the cell cycle, and uptake and incorporation of the tracers into DNA, RNA, and protein of algal cells were examined. They showed more or less characteristic patterns in the process studied. The three kinds of macromolecular cell constituents took up the radioactivities of all the compounds tested, except in the case of $\left[6-{ }^{3} \mathrm{H}\right]-$ thymidine, whose radioactivity was incorporated into DNA and protein but not into RNA. ${ }^{14} \mathrm{C}$ of $\mathrm{CO}_{2}$ seemed to be specifically or preferentially incorporated into chloroplast macromolecules under photosynthesizing conditions.
\end{abstract}

Since the existence of a DNA species in the chloroplasts of Chlorella was suggested by IwAMURA (1), many studies have been made along the relevant line. It has now been established that such cell organelles as chloroplasts and mitochondria contain not only unique DNA species of their own, but ribosomes and some tRNAs which differ from those found in cytosol, and that these cell organelles have ability to synthesize DNA, RNA, and protein, thus giving a biochemical basis for the cytologically observed autonomy of the organelles within the whole cell (2-5).

The development of an elaborate technique of synchronous culture of Chlorella (6-8) has enabled us to investigate in detail subcellular as well as cellular events occurring during the algal cell cycle, and the studies are now in progress on different modes of behaviour of various cell organelles during the cell cycle.

In the present study, the algal cells, at different stages of the cell cycle, were 
fed for a definite period of time $(1 \mathrm{hr})$ with eight different substances which were labelled with either ${ }^{3} \mathrm{H},{ }^{14} \mathrm{C}$, or ${ }^{32} \mathrm{P}$, and the degree of uptake of the compounds by algal cells as well as the incorporation of the tracers into DNA, RNA, and protein in the cells was followed. The labelled compounds fed to the alga included, besides $\mathrm{CO}_{2}$, inorganic phosphates and acetate, an amino acid (leucine), and two kinds each of nucleosides and their bases (thymidine, uridine, thymine, and uracil). It should be noted beforehand that most of the organic compounds tested seem to be metabolized in some way or other before their radioactive tracers are incorporated into the three macromolecular substances. This was evidenced by the fact that the tracer of leucine was found in nucleic acids and those of the nucleosides and their bases in protein.

\section{MATERIALS AND METHODS}

Synchronous culture of Chlorella cells. Chlorella ellipsoidea was synchronously grown by the technique developed by TAMIYA and his colleagues $(7,9)$. Wellsynchronized "DLD-cycle" was obtained by subjecting the culture repeatedly to a light period of $18 \mathrm{hr}$ followed by a dark period of $9 \mathrm{hr}$. The culture temperature was $21^{\circ}$. The culture vessel used was essentially the same as that reported by MORIMURA et al. (10), being made of Lucite acrylate resin and having a capacity of 20 liters. Cell suspension of $5 \mathrm{~cm}$ in thickness was illuminated from both sides of the plane parallel walls of the vessel, each by using a bank of fluorescent lamps. The light intensity at the surface of the vessel walls was about $10 \mathrm{klx}$. The culture medium was the same as that reported previously (6) with some modifications $\left(\mathrm{KNO}_{3}, 1.25 \mathrm{mg} / \mathrm{ml} ; \mathrm{pH}\right.$ adjusted to 6.0 with $\left.\mathrm{KOH}\right)$, and $5 \% \mathrm{CO}_{2}$-air was bubbled through the cell suspension.

The cell density was kept below $1 \mu \mathrm{l} / \mathrm{ml}$ in terms of "packed cell volume," which was measured by centrifuging an appropriate volume of the cell suspension in a hematocrit at $1,700 \times g$ for $40 \mathrm{~min}$. The cell samples used in the "isotopefeeding experiments" were harvested from the culture after establishment of the regular DLD-cycle. Immediately after each harvest, the culture was diluted with an appropriate volume of the fresh culture medium so that the cell density at the next harvest would become $1 \mu \mathrm{l} / \mathrm{ml}$.

Isotope-feeding experiments. The labelled compounds were supplied to algal cells at the following specific activities and concentrations in the incubation medium:

${ }^{14} \mathrm{CO}_{2}, 2.5 \mu \mathrm{Ci} / 2.5 \mu \mathrm{mol} / \mathrm{ml} \mathrm{CO}$-air; ${ }^{32} \mathrm{P}$-phosphates $\left(\mathrm{P}_{\mathrm{i}}\right), 4.0 \mu \mathrm{Ci} / 9.2 \mu \mathrm{mol} /$ $\mathrm{ml}$; $\left[2-{ }^{14} \mathrm{C}\right]$ acetate $(\mathrm{Ac}), 0.20 \mu \mathrm{Ci} / 4.1 \mathrm{nmol} / \mathrm{ml} ; \mathrm{L}-\left[4,5-{ }^{3} \mathrm{H}\right]$ leucine (Leu), $1.0 \mu \mathrm{Ci} /$ $0.031 \mathrm{nmol} / \mathrm{ml} ;\left[6-{ }^{3} \mathrm{H}\right]$ thymidine $(\mathrm{dT}), 1.0 \mu \mathrm{Ci} / 0.10 \mathrm{nmol} / \mathrm{ml} ;\left[5-{ }^{3} \mathrm{H}\right]$ uridine $(\mathrm{U})$, $0.20 \mu \mathrm{Ci} / 0.017 \mathrm{nmol} / \mathrm{ml} ;\left[2-{ }^{14} \mathrm{C}\right]$ thymine (Thy), $0.20 \mu \mathrm{Ci} / 3.9 \mathrm{mmol} / \mathrm{ml} ;\left[2-{ }^{14} \mathrm{C}\right]-$ uracil (Ura), $0.20 \mu \mathrm{Ci} / 3.9 \mathrm{mmol} / \mathrm{ml}$.

(Abbreviations standing for the compounds, which will be used hereafter, are shown in parentheses.) 
Each labelled compound was supplied to the cell samples taken out at different stages of cell cycle; namely, at $0,2,4,6,8,10,12,14,16,18,21$, and $24 \mathrm{hr}$ from the beginning of the light period. These stages will be denoted hereafter by $T_{0}, T_{2}$, etc. Except in the case of $\mathrm{CO}_{2}, 4.0 \mathrm{ml}$ each of the cell suspension was taken out from the main synchronous culture and transferred to a flat oblong glass vessel of about $50 \mathrm{ml}$ in capacity ( $c f$. (6)). After addition of a labelled compound, the cells were cultured (incubated) for $1 \mathrm{hr}$ under the same conditions as those for the main synchronous culture. In the case of $\mathrm{CO}_{2}, 7.0 \mathrm{ml}$ of the harvested cell suspension was placed in a vessel (similar in shape to that of Warburg's manometer) of about $50 \mathrm{ml}$ in total capacity, and, under illumination, it was shaken with $5 \% \mathrm{CO}_{2}$-air containing ${ }^{14} \mathrm{CO}_{2}$.

The 1-hr incubation with the labelled compound was carried out under illumination with the cells at the stages from $T_{0}$ to $T_{18}$, and in the dark with the cells at $\mathrm{T}_{21}$ and $\mathrm{T}_{24}$ except in the case of $\mathrm{CO}_{2}$ and $\mathrm{P}_{\mathrm{i}}$, in which recognizable assimilation by algal cells took place only in the light. After the incubation, the cell suspension was immediately chilled with ice, and aliquots (100 and $200 \mu \mathrm{l})$ of the cell suspension were withdrawn to assay the radioactivity of the whole algal cells. The remaining cells were harvested with a refrigerated centrifuge, washed with icechilled deionized water, and stored in a freezer until use for fractionation of cell materials. From each of the harvests the cell sample for the fractionation was prepared in duplicate, each containing algal cells in an amount of about $10 \mathrm{mg}$ in dry weight.

Fractionation of cell materials. The labelled cells stored in a freezer were subjected to a modified Schmidt-Thannhauser method to obtain RNA, DNA, and protein fractions. The details of the fractionation procedure were almost the same as those described in a previous paper (11). The defatted, depigmented cell materials obtained after extraction of acid-soluble fraction were hydrolyzed with $\mathrm{NaOH}$. The resulting alkaline hydrolysates were clarified by centrifugation and divided into two parts; one part was used for quantitative assays of DNA, RNA, and protein after further fractionation, and the other part was used for assays of radioactivities of the three macromolecular substances as will be described later. The RNA fraction was obtained by acidification of the clear alkaline hydrolysates with perchloric acid, and the precipitates obtained were hydrolyzed with the acid to obtain the DNA fraction as a solution and the protein fraction as the residual precipitate. Both nucleic acids were assayed on the respective fractions by UV spectrophotometry, and protein on aliquots of the clear alkaline hydrolysates by Lowry's method using Fraction V of bovine serum albumin (Sigma Chemical Co., U. S. A.) as the standard.

Measurement of radioactivity. (a) Whole cells. Aliquots of algal cell suspension (100 and $200 \mu \mathrm{l}$ ), which had been supplied with a labelled compound, were filtered through a Millipore filter (HA, $0.45 \mu \mathrm{m}$ pore size, $25 \mathrm{~mm}$ in diameter), and the cells collected on the filter were washed once with $10 \mathrm{ml}$ of a solution con- 
taining the unlabelled compound and more than four times with $10 \mathrm{ml}$ each of deionized water. The cell samples thus obtained were dried at room temperature and counted in Bray's scintillation fluid in a liquid scintillation counter except in the case of $P_{i}$, for which Cerenkov radiation was utilized in the counter at the settings for ${ }^{3} \mathrm{H}$ by the use of water instead of the scintillation fluid. The quenching under these conditions for each of the radioisotopes was assayed against a wet-ashing method (12) for the cell samples on the filter, and the values of the efficiency obtained were $8.51 \%$ for ${ }^{3} \mathrm{H}, 33.5 \%$ for ${ }^{14} \mathrm{C}$, and $30.0 \%$ for ${ }^{32} \mathrm{P}$.

(b) $D N A, R N A$, and protein. The reserved aliquot of the clear alkaline hydrolysates was acidified to obtain the RNA fraction and the (DNA+protein) fraction. In order to remove the ribonucleotides completely, the (DNA+protein) fraction was once redissolved in alkali, reprecipitated with an acid, and washed thoroughly with an acid. The (DNA + protein) fraction thus obtained was redissolved in alkali, neutralized, and then digested with a DNase (EC. 3. 1. 4. 5) to obtain deoxyribonucleotides of algal DNA. Both the ribo- and deoxyribo-nucleotides thus obtained were purified by treatment with Dowex- $\left(\mathrm{Cl}^{-}\right)$and Norite A, and then assayed by UV spectrophotometry and radioactivity.

In most cases, protein assay was performed with the protein fraction obtained after the acid hydrolysis of the (DNA + protein) fraction. Before the assay, the fraction was redissolved in alkali, reprecipitated with an acid, and after repeated washing with the acid the precipitates were redissolved in alkali and neutralized. In the cases of $\mathrm{CO}_{2}$ and $\mathrm{P}_{\mathrm{i}}$ the radioactivity was measured of the amino acids obtained by digesting the defatted, depigmented cell materials containing about $2 \mathrm{mg}$ of algal protein with $10 \mu \mathrm{g}$ of Pronase (Kaken Chemical Co., Ltd., Tokyo) at $37^{\circ}$ for $4 \mathrm{hr}$. The amino acids thus obtained were purified by paper chromatography using butanol-acetic acid-water $(4: 1: 2, \mathrm{v} / \mathrm{v})$ system, and the eluates obtained from the region of paper, which gave a positive Ninhydrin test, were assayed by the Ninhydrin method and their radioactivities were counted. The amino acid mixture used as the standard for the Ninhydrin method was prepared according to the data reported by KANAZAWA (13) concerning the amino acid composition of the cells of Chlorella ellipsoidea. Essentially the same results were obtained, in the case of $\mathrm{CO}_{2}$, in the two sets of experiments which differed in the procedure for purifying the protein fraction for assay of radioactivity, indicating the validity of the simpler method (without the use of Pronase), which was adopted for most of the labelled compounds. (The data presented in this report for both $\mathrm{CO}_{2}$ and $\mathrm{P}_{\mathrm{i}}$ were obtained by the method using Pronase).

From the solutions of nucleotides, protein, or amino acids, $1 \mathrm{ml}$ each was taken out and placed in a scintillation fluid, and the radioactivity was counted using a Packard TriCarb Liquid Scintillation Spectrometer Model 2311 or 3411. The quenching was measured by the use of labelled standards for each of the three radioisotopes. 


\section{RESULTS AND DISCUSSION}

Growth curves and changes in contents of DNA, RNA, and protein during the course of algal cell cycle

The curves in the upper part of Fig. 1 show the course of algal growth in the main synchronous culture starting from the D-cells; the light period lasted for $18 \mathrm{hr}\left(\mathrm{T}_{0} \rightarrow \mathrm{T}_{18}\right)$, which was followed by 9 -hr dark period. The value denoted by $\overline{\mathrm{v}}$ shows the "mean cell volume," which was obtained by dividing the packed cell volume by the cell number in a volume of culture at each harvest time. The value $\mathrm{r}_{\mathrm{N}}$ represents the "relative cell number," $i$. e., the ratio of the cell number at $\mathrm{T}_{t}$ (the $t$-hr) to the cell number at $\mathrm{T}_{0}$. Both $\overline{\mathrm{v}}$ and $\mathrm{r}_{\mathrm{N}}$ were plotted on a common logarithm scale against the culture hour. It can be seen that during the light period the cell volume (or cell mass) increased exponentially and that the value $\bar{v}$ at $T_{18}$ was four times as large as that at $T_{0}$. The cellular division (liberation of four daughter cells from a mother cell) started to occur at about $T_{19}$, and was completed by $T_{26}$, during which time the relative cell number increased four times and the mean cell volume was reduced to the level at $T_{0}$. It should be noted that during the period from $T_{19}$ to $T_{24}$ the cell population consisted of mature mother cells and newly produced daughter cells, in increasing ratio of the latter with lapse of time.

In the lower part of Fig. 1 are shown the courses of changes in contents, on per cell basis, of protein, RNA, and DNA. The black squares, triangles, and circles

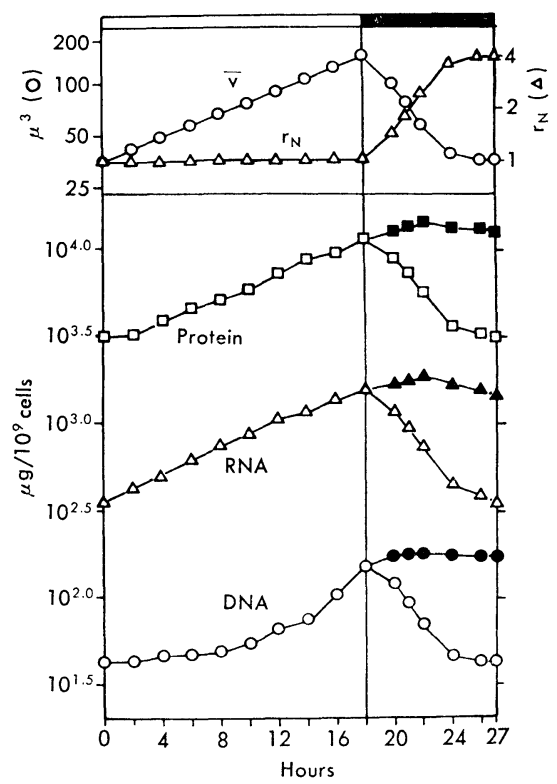

Fig. 1. Growth curves and changes in contents of DNA, RNA, and protein of synchronized Chlorella cells during the cell cycle.

The light and dark periods are distinguished by the blank and black horizontal bars at the top of the graph. As to the black squares, triangles, and circles see the text. 
given for the dark period show the total quantities of the substances contained in the mixture of mother cells and daughter cells as expressed in terms of those per number of mother cells existing at the end of the light period. As can be seen from these graphs, the quantities of protein and RNA increased during the light period, almost in parallel with the cell volume, while that of DNA showed only a slow increase at the early stages of the light period and a marked increase at the later stages of the same period. All these phenomena are essentially in conformity with those reported earlier by IwAmuRA (14), using “ $D_{\mathrm{s}} L D$ '-cycle."

A very slight but significant increase of the DNA content can be seen during the period of $\mathrm{T}_{4}-\mathrm{T}_{8}$; the increment at $\mathrm{T}_{8}$ was $11.7 \%$ of the DNA content at $\mathrm{T}_{0}$. A more distinct uprise in the content took place during the period of around $\mathrm{T}_{8}-\mathrm{T}_{12}$; the increment at $\mathrm{T}_{12}$ was $54.1 \%$ of the DNA content at $\mathrm{T}_{0}$. As has been shown by the data reported previously (15), the latter increase is mainly due to the replicative synthesis of chloroplast DNA (chDNA), whose content amounts at least to $10 \%$ of the total DNA content in the D-cells (16). The marked increase of DNA content which occurred during the period from $T_{14}$ to $T_{18}$ is attributable mainly to the replicative synthesis of nuclear DNA (nDNA); the DNA content reached the value four times that at $T_{0}$. With the completion of cellular division, the concentration per cell returned to the level observed at $T_{0}$.

Electron microscopic observations made of the algal cells at various stages of our synchronous culture have revealed that, during the light period, the first division (or constriction) of chloroplast seems to take place during the period of $\mathrm{T}_{14}-\mathrm{T}_{16}$, and the resulting two daughter chloroplasts divide further into two each at around $\mathrm{T}_{18}(c f .(17))$. It is interesting to note that the algal cells at the stage around $\mathrm{T}_{4}-\mathrm{T}_{6}$ seem to contain a large single mitochondrion adhering, along its long axis, closely to the chloroplast $(c f .(18-20))$. The division or partition of mitochondrion, probably preceded by the increase in size, seems to occur-starting from the stage at $\mathrm{T}_{14}$-in parallel with that of chloroplast. Lagging somewhat behind these events, the division of cell nucleus takes place (starting around $\mathrm{T}_{16}$ ), simultaneously with the division of the whole cell content (cytokinesis) occurring successively twice. All these events occur to give rise to four daughter cells within the original mother cell wall. Liberation of these daughter cells from the mother cell starts at around $T_{19}$ and comes almost to completion by $T_{24}$.

Based on these observations as well as the experimental results presented in Fig. 1, it is thought pertinent to distinguish the following stages in the cell cycle under the experimental conditions:

Stage I, $\mathrm{T}_{0} \rightarrow \mathrm{T}_{4}$; Stage II, $\mathrm{T}_{4} \rightarrow \mathrm{T}_{8}$; Stage III, $\mathrm{T}_{8} \rightarrow \mathrm{T}_{12}$; Stage IV, $\mathrm{T}_{12} \rightarrow \mathrm{T}_{14}$; Stage V, $T_{14} \rightarrow T_{18} ;$ Stage VI, $T_{18} \rightarrow T_{24} ;$ Stage VII, $T_{24} \rightarrow T_{27}$.

Uptake of various labelled compounds by algal cells in the "isotope-feeding experiments"

In the "isotope-feeding experiments," all the compounds tested were quickly 


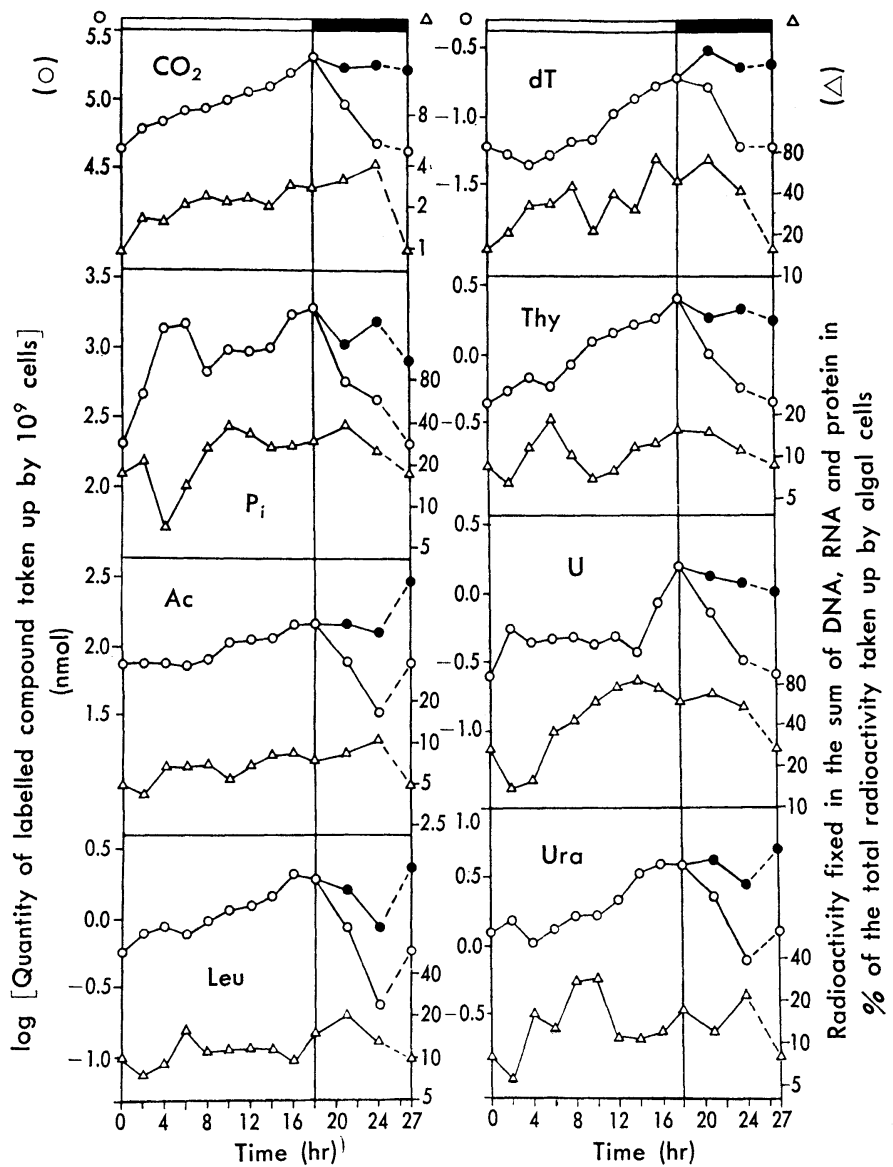

Fig. 2. Uptake of various labelled compounds and incorporation of their radioisotopes into the sum of DNA, RNA, and protein during the 1-hr feeding experiments.

The letters in the figure are abbreviations of the names of the labelled compounds fed to algal cells. See also the legend for Fig. 1.

taken up by algal cells and their radioisotopes were further incorporated into the three macromolecular cell constituents, DNA, RNA, and protein. Figure 2 shows the changes in the cellular activity to take up each of the labelled compounds during the cell cycle, and changes in the quantities of radioactivities incorporated into the sum of the three macromolecular species in percentage of the total uptake of the compound. (The values for the uptake per unit cell number were plotted on a common logarithm scale.) As was the case in Fig. 1, the black dots given for the dark period refer to the total quantities contained in the mixture of mother cells and daughter cells as expressed in terms of those per number of mother cells which existed at the end of the light period.

We can see that the curves for the total uptake obtained with $\mathrm{CO}_{2}$, Leu, dT, 
Thy, and Ura more or less resemble in shape that of the mean cell volume shown in Fig. 1, which was not the case in the curves for $P_{i}, A c$, and $U$. The degree of uptake of the former group, thus, seems to be roughly proportional to the size (mass) of algal cells at each stage of cellular development. It may be noteworthy that Ac showed a unique curve for the total uptake, in which the value at $T_{18}$ was seen to be at most two times as large as that at $T_{0}$, making a marked contrast to all the other compounds.

\section{Radioactivities fixed in nucleic acids and protein}

The amount of radioactivity fixed in each of the three macromolecular substances was measured, and, for each of the compounds fed to algal cells, the following two sets of values were calculated:

(1) Mol-equivalent of radioactivity of the labelled compound incorporated in mol of nucleotides (in the case of nucleic acids) or of amino acids (in the case of protein). The degree of fixation thus expressed is referred to as "specific incorporation" and denoted by SI.

(2) Mol-equivalent of radioactivity fixed in total nucleotides (in the case of nucleic acids) or in total amino acids (in the case of protein) contained in $10^{9}$ cells. This is called "total incorporation" and denoted by TI.

In Figs. 3, 4, and 5, both these values are plotted on a common logarithm scale against the culture hour. The meaning of the black dots given for the dark period in the graphs is the same as that of the black dots in Fig. 2.

(a) DNA. As shown in Fig. 3, the radioisotopes of all the compounds tested were incorporated into algal DNA at all the stages of cell cycle, the mode of incorporation being, however, different from one compound to another. We have seen from Fig. 1 that during the light period DNA per a definite number of cells increased slowly at first and later rapidly, while in the subsequent dark period it decreased markedly corresponding to the occurrence of cellular division. Similar courses were found in the TI-curves for Leu, dT, and Ura, while for the other compounds no such resemblance could be observed.

The fact that the SI-curve for Leu remained fairly even through the cell cycle indicates that the incorporation of its tracers into DNA reflects fairly faithfully the cellular activity in syntheses of various DNAs. An interesting phenomenon was observed with $\mathrm{dT}$, which has widely been utilized in the investigation of cellular DNA synthesis. Both for SI and TI, the curves of dT showed three distinct uprises; (1) first that at Stage I, (2) then that at Stage III, followed by (3) that occurring during the period of $T_{14}-T_{21}$ (mainly at Stage $V$ ). It is noteworthy that the uprises (2) and (3) occurred, respectively, at the time of syntheses of chDNA and nDNA.

Of special interest is the phenomenon observed with $\mathrm{CO}_{2}$, which showed a striking uprise at Stage III. The DNA labelled with $\mathrm{CO}_{2}$ at Stage III has been revealed to consist of a few DNA species having a buoyant density in $\mathrm{CsCl}$ of around $1.69-1.72 \mathrm{~g} / \mathrm{ml}(21)$, a value which coincides with those of chDNA (16). 


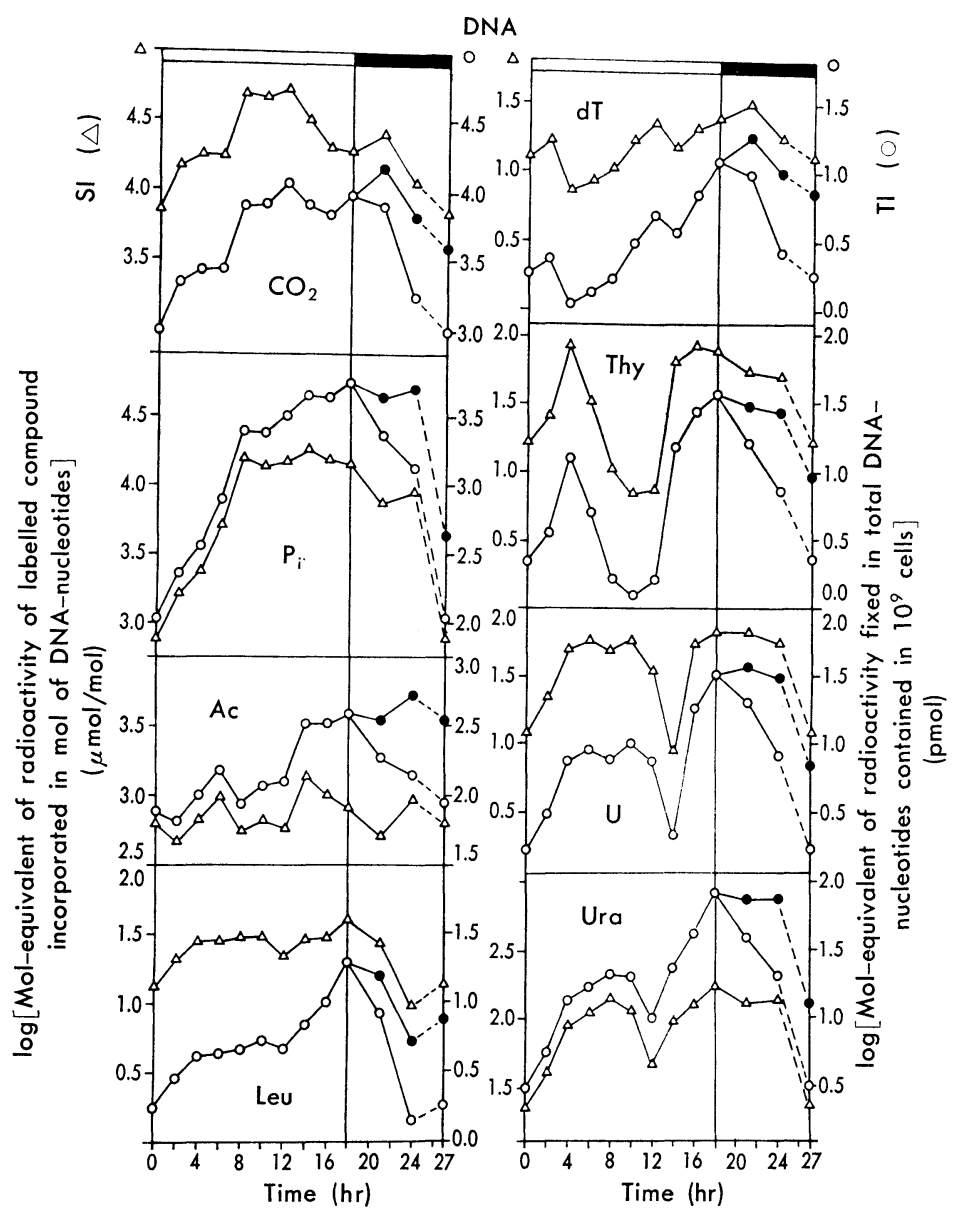

Fig. 3. Changes in the SI- and TI-values for DNA on provision of various labelled compounds in the feeding experiments.

For the definitions of SI- and TI-values, see the text. See also the legend for Fig. 2.

It seems, therefore, reasonable to infer that the uprises of SI- and TI-curves for $\mathrm{CO}_{2}$ at Stage III are mainly due to the synthesis of chDNA occurring at this stage.

Unlike the curves for $\mathrm{CO}_{2}$, those for Ac and Thy showed more or less profound dents at Stage III. This fact may be interpreted as indicating that the radioisotopes of these two compounds were utilized only inefficiently by the chloroplast for its DNA synthesis. The DNA species that are labelled strongly on supply of Ac at around $T_{6}$ and $T_{14}$ have been revealed to be the so-called satellite DNAs (22). Since acetate is known to enter rapidly into the Krebs cycle in the alga (23), it is intriguing hypothesis that Ac is rapidly converted into some components of deoxyribonucleotides upon its uptake, being further incorporated into mitochondrial DNA at certain stages of the cell cycle. 
To sum up, the radioisotopes in all the compounds tested in the feeding experiments seem to have been incorporated mainly into newly synthesized DNA species, which are, in the case of $\mathrm{CO}_{2}$, specifically those of chloroplast at a definite stage, and, in the case of Ac, presumably those of mitochondrion.

(b) $R N A$. The radioisotopes contained in all the compounds tested, except that in $\mathrm{dT}$, were found to be incorporated into algal RNA. Among the TI-curves presented in Fig. 4, those for $\mathrm{CO}_{2}, \mathrm{P}_{\mathrm{i}}$, Leu, and $\mathrm{U}$ show, during the light period, relatively smooth uprising courses which are, although very roughly, similar to that of the curve for RNA given in Fig. 1. This suggests that the radioisotopes in these compounds were incorporated into RNA approximately in proportion to the total RNA present in algal cells.

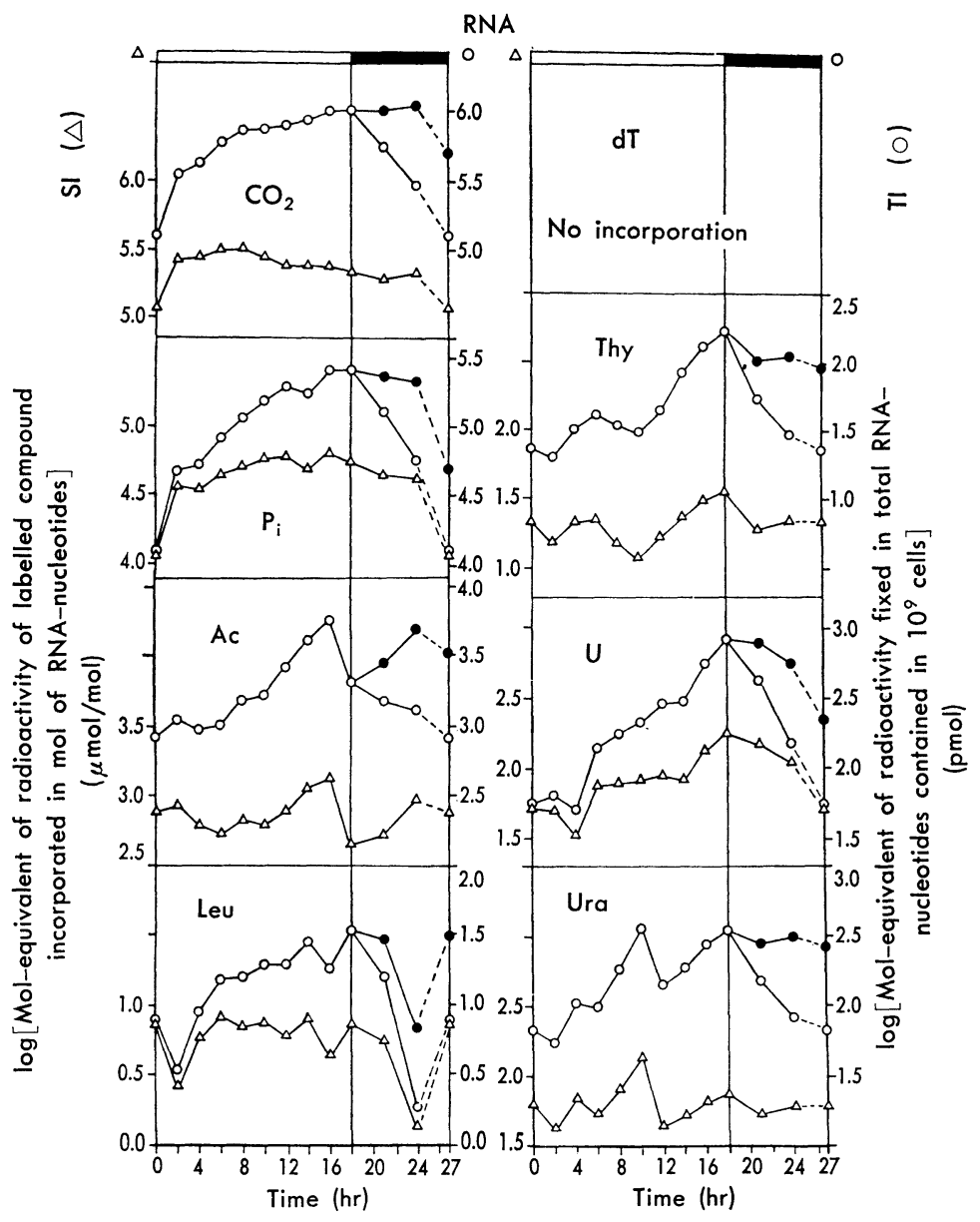

Fig. 4. Changes in the SI- and TI-values for RNA on provision of various labelled compounds in the feeding experiments.

See also the legend for Fig. 3. 
The SI-curves for $\mathrm{CO}_{2}$ and $\mathrm{P}_{\mathrm{i}}$ have some similarity, showing a marked uprise at the beginning and no conspicuous changes during the rest of the light period. In the case of $\mathrm{CO}_{2}$, however, the value of SI was the highest at Stage II, gradually decreasing with the culture hour to reach the minimum in the small cells. TI showed an increase in both the earlier and later stages, but a cease at Stage III, i.e., the period of chDNA synthesis. It has previously shown (15) that chloroplast RNA (chRNA), the amount of which is mainly contributed by the chloroplast ribosomal RNAs, increases roughly in an exponential manner from the beginning till the middle of the light period, and it ceases to increase during the period of chDNA synthesis, after which it is again synthesized. Thus, the incorporation pattern for $\mathrm{TI}$ in the case of $\mathrm{CO}_{2}$ seems to resemble not the synthetic pattern for the whole cell RNA but rather that for chRNA during the course of cell cycle, suggesting that the preferential labelling occurs for chRNA in the case of $\mathrm{CO}_{2}$.

It should be noted that $U$ and Ura, whose behaviour as building blocks for RNA synthesis in various living organisms has been extensively studied, gave markedly different types of curve for both SI and TI. The SI-curve for U showed a marked ascension at around the stage of vigorous nDNA synthesis, while that for Ura rose temporarily during the period of chDNA synthesis.

As was in the case of DNA, the SI-curve for Ac showed the highest value around $\mathrm{T}_{14}$, which made a marked contrast to all the other compounds.

(c) Protein. The SI- and TI-curves obtained for protein in algal cells are shown in Fig. 5. The TI-curves for $\mathrm{CO}_{2}$ and Leu showed resemblance in shape to the curves for the total uptake for $\mathrm{CO}_{2}$ and Leu, respectively, in Fig. 2. This resemblance seems to be due to the fact that both $\mathrm{CO}_{2}$ and Leu were incorporated into protein in a considerably larger amount than into nucleic acids. The SIcurve for Leu was almost on a constant level during the light period (except at $T_{6}$ ), indicating that the incorporation of its tracer into protein reflected fairly faithfully the synthetic pattern of whole cell protein during the cell cycle. This does not seem to have been the case with $\mathrm{CO}_{2}$; the SI-curve for $\mathrm{CO}_{2}$ showed two distinct dents before and after the period of chDNA synthesis, which again might infer that the pattern had reflected closely that of protein synthesis in the chloroplast.

In the case of $\mathrm{AC}$, the SI-value was maximal at $\mathrm{T}_{4}$ and thereafter gradually decreased through the light period. The TI-curve for Ac also differed distinctly from those of $\mathrm{CO}_{2}$ and Leu. It is remarkable that the tracers of both the nucleosides and their bases were incorporated considerably into protein, and they showed much more undulations than the former three, $\mathrm{CO}_{2}$, Leu, and Ac.

Very unique patterns for both SI and TI were obtained in the case of $P_{i}$; they showed conspicuous undulations throughout the cell cycle. The meaning of the undulations remains obscure, but it is worthy to note that each of the peaks in the curves seems to be situated at the period of active synthesis of each of the several DNA species mentioned already.

(d) General discussion. Eukaryotic cells contain many kinds of cell organelles 


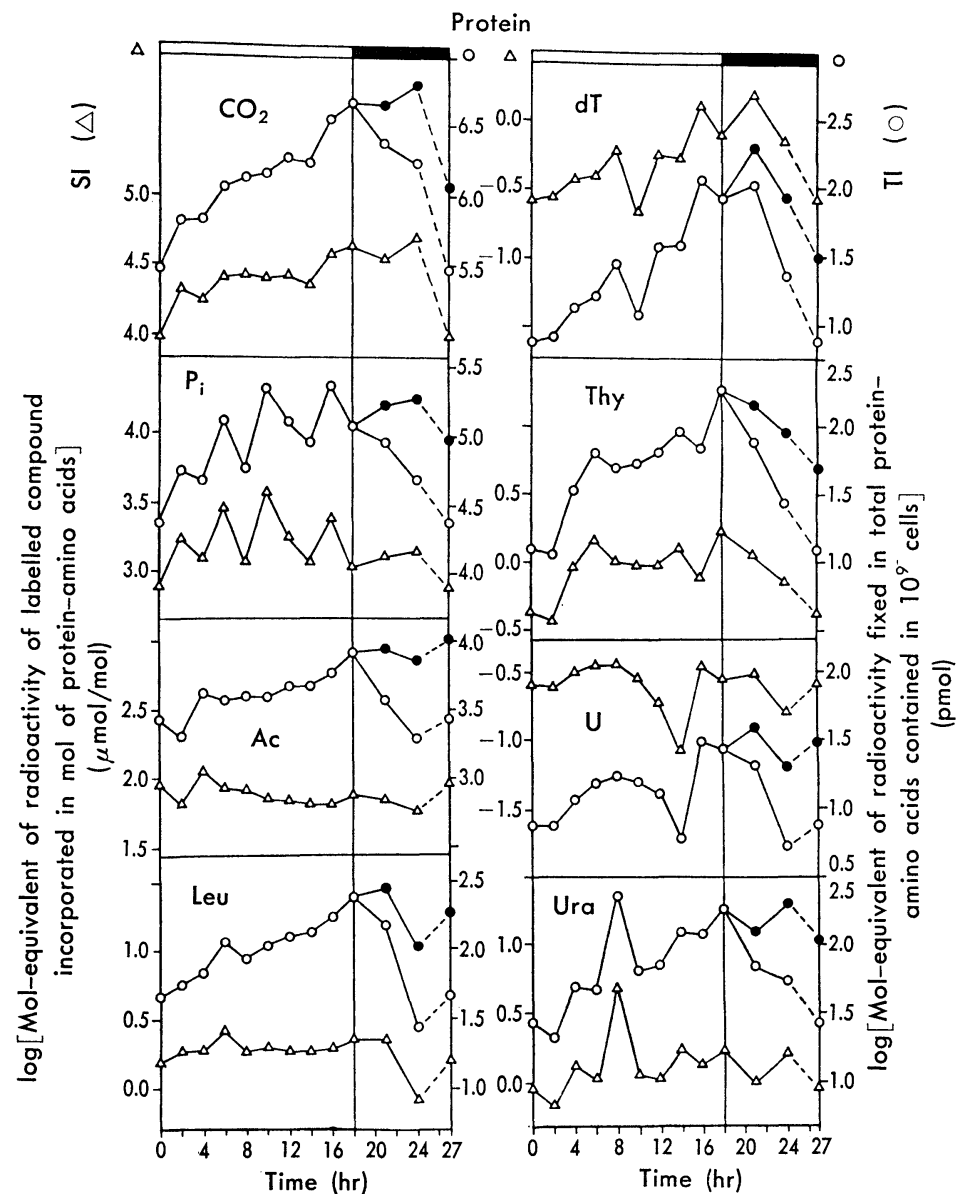

Fig. 5. Changes in the SI- and TI-values for protein on provision of various labelled compounds in the "feeding experiments".

See also the legend for Fig. 3.

besides nucleus. Some of them have long been known to be seemingly autonomous within the mother cell, to which biochemical bases have recently been accumulated. Uptake of a radioisotopically labelled compound by eukaryotic cells fed externally to them and further incorporation of the tracers into cellular macromolecular substances ("uptake and incorporation") must be observed as the resultant of various activities of many kinds of cell organelles to utilize the compound and/or its derivatives, which may change with the progress of cellular development during the cell cycle. Some of the compounds may be preferentially or specifically utilized by a certain cell organelle at a definite stage or throughout the cell cycle. The complicated patterns of the "uptake and incorporation" obtained for each of the compounds tested in this study may be considered to be the reflection of such a situation. 
They are no doubt characteristic of each compound, but it is also noticed that the cellular activities in the "uptake and incorporation" increase, in general, with the increase in the cell mass on one hand, and on the other, they are more or less affected by the developmental events occurring successively during the course of cell cycle, typically for example, by the successive occurrence of DNA synthesis in each of the cell organelles.

As we have seen, the radioisotopes of all the compounds taken up by algal cells were incorporated into nucleic acids and protein with only one exception of dT, whose tracer ${ }^{3} \mathrm{H}$ could not be incorporated into RNA. The significant incorporation, as revealed by the TI-values, of ${ }^{3} \mathrm{H}$ of Leu into nucleic acids and that of ${ }^{14} \mathrm{C}$ of Thy and Ura as well as that of ${ }^{3} \mathrm{H}$ of $\mathrm{dT}$ and $\mathrm{U}$ into protein indicates that all these labelled compounds were not incorporated as such into the respective macromolecules. This phenomenon may be due to the fact that we are dealing with the cells of eukaryotic nature as well as of unicellular microbes growing actively under autotrophic conditions. What biochemical changes those labelled compounds do undergo before their derivatives are assimilated into the macromolecules is an interesting problem left open, and it is, at this moment, worth referring that we should be very careful about interpretation of the results obtained by using radioisotopically labelled compounds to investigate cellular synthetic activities of nucleic acids and protein, especially in the case of eukaryotic cells.

It is intriguing that a possibility for "specific or preferential labelling" of macromolecules in cell organelles has been turned up in this study, as exemplified in the case of $\mathrm{CO}_{2}$. Further elaboration to explore the possibility is now in progress in our laboratory.

This work was supported by a Grant-in-Aid for Scientific Research from the Ministry of Education, Science and Culture, of Japan. We express our thanks to Prof. E. Hase of The University of Tokyo for his kind reading of the manuscript.

\section{REFERENCES}

1) T. Iwamura, Biochim. Biophys. Acta, 42, 161 (1960).

2) T. Imamura, Prog. Nucleic Acid Res. Mol. Biol., 5, 133 (1966).

3) S. Granick and A. Gibor, Prog. Nucleic Acid Res. Mol. Biol., 6, 143 (1967).

4) K. K. Tewari, Annu. Rev. Plant Physiol., 22, 141 (1971).

5) P. Borst, Annu. Rev. Biochem., 41, 333 (1972).

6) H. Tamiya, T. Imamura, K. Shibata, E. Hase, and T. Nihei, Biochim. Biophys. Acta, 12, 23 (1953).

7) H. Tamiya, Y. Morimura, M. Yokota, and R. Kunieda, Plant Cell Physiol., 2, 383 (1961).

8) H. TamiYa, Annu Rev. Plant Physiol., 17, 1 (1966).

9) H. TamiYa and Y. Morimura, In Synchrony in Cell Division and Growth, ed. by E. Zeuthen, John Wiley \& Sons, Inc., New York (1964), p. 565.

10) Y. Morimura, S. Yanagi, and H. TamiYa, Plant Cell Physiol., 5, 281 (1964).

11) T. IWAmura, H. NAGAI, and S. Ichimura, Int. Rev. Gesamtcu Hydrobiol., 55, 131 (1970).

12) D. T. MAhin and R. T. LofBerg, Anal. Biochem., 16, 500 (1966). 
13) T. Kanazawa, Plant Cell Physiol., 5, 333 (1964).

14) T. Iwamura, J. Biochem. (Tokyo), 42, 161 (1955).

15) T. Iwamura, Ann. N. Y. Acad. Sci., 175, 486 (1970).

16) T. Iwamura and S. Kuwashima, Biochim. Biophys. Acta, 174, 330 (1969).

17) S. Murakami, Y. Morimura, and A. TakamiYa, In Studies on Microalgae and Photosynthetic Bacteria, ed. by Japanese Society of Plant Physiologists, University of Tokyo Press, Tokyo (1963), p. 65.

18) R. Calvayrac, F. Van Lente, and R. A. Butow, Science, 173, 252 (1971).

19) T. Osafune, S. Mihara, E. Hase, and I. Ohkura, Plant Cell Physiol., 13, 211 (1972).

20) A. W. Atkinson, Jr., P. C. L. John, and B. E. S. Gunning, Protoplasma, 81, 77 (1974).

21) K. Katoh, T. Nishimura, and T. Iwamura, Seikagaku, 47, 680 (1975), in Japanese.

22) K. KАTOH, T. Nishimura, and T. Iwamura, Seikagaku, 44, 746 (1972), in Japanese.

23) K. Fujita, J. Biochem. (Tokyo), 46, 253 (1959). 